\title{
PENGARUH METODE PROYEK TERHADAP KEMAMPUAN SOSIAL ANAK KELOMPOK A DI RA AL CHUSNANIYAH SURABAYA TAHUN AJARAN 2017-2018
}

\author{
Mira Dahlia \\ RA AL Chusnaniyah Surabaya \\ Email: mira.dahlia.14@gmail.com
}

\begin{abstract}
ABSTRAK
Dampak Metode Proyek terhadap Kemampuan Sosial Siswa Grup A di RA AL Chusnaniyah Surabayain tahun akademik 2017-2018 adalah metode pembelajaran yang bertujuan untuk menerapkan kegiatan pengalaman belajar dengan mengkonfrontasi anak-anak pada masalah sehari-hari yang harus diselesaikan dalam kelompok. Tujuan penulisan untuk persyaratan kelulusan dalam program pendidikan guru, dan sebagai referensi guru PAUD dalam merancang kegiatan pembelajaran yang menarik serta mengembangkan keterampilan sosial anak usia dini. Metode yang digunakan dalam penelitian ini adalah metode kuantitatif karena menguji teori yang berkaitan dengan masalah penelitian melalui kerangka berpikir yang dirumuskan dalam hipotesis penelitian. Teknik pengumpulan data menggunakan teknik eksperimen, dengan melakukan uji beda dua kelas yang berbeda. Hasil yang diperoleh dari penelitian ini adalah, ada pengaruh yang lebih efektif untuk mengembangkan kemampuan sosial anak-anak di RA Al Chusnaniyah Surabaya dengan menggunakan metode proyek dalam pembelajaran di sekolah.
\end{abstract}

Kata Kunci : medoode proyek, kemampuan sosial

ABSTRAK

The impact of Project Method on Students' Social Ability of Group A in RA AL Chusnaniyah Surabayain the academic year 2017-2018 is a learning method that aims to apply activities of learning experiences by confronting children on daily issues that must be solved in groups. The purpose of writing for graduation requirements in teacher education programs, and as a reference PAUD teachers in designing interesting learning activities as well as develop social skills of early childhood. The method used in this research is quantitative method because it test the theory related to the research problem through the framework of thinking formulated in the research hypothesis. The data collection technique used experiment technique, by doing test difference of two different class. The results obtained from this research are, there is a more effective effect to develop social ability of children in RA Al Chusnaniyah Surabaya by using the project method in learning in school.

Keywords: Projects Method; Social Capability

\section{PENDAHULUAN}

Istilah proyek dari kata latin yang berarti: proyektum yang berarti tujuan, rangcangan, rencana, dangan maksud tertentu yang mempunyai perencanaan yang baik dalam kegiatan pembelajaran. Secara epistimologi motode proyek memiliki pengertian sebagai cara penyajian pelajaran yang bertitik tolak dari suatu masalah, kemudian dibahas dari berbagai segi yang berhubungan sehingga pemecahannya secara keseluruhan dan bermakna. 


Metode proyek termasuk
dalam pembelajaran kooperatif
yang merupakan $\begin{array}{r}\text { metode } \\ \text { dalam }\end{array}$
pembelajaran
pelaksanaanya membagi anak
dalam kelompok-kelompok satu
dengan yang lain bekerja sama
dan berpartisipasi dalam belajar
dan bertanggung jawab satu sama
lain. Imam Ghazali berpendapat:
"Pendidikan tidak boleh hanya
mengisi pikiran dengan ilmu, dan
pada saat yang sama anak harus
diberi dorongan moral dan bekal
untuk hidup bermasyarakat".
(Ahmad, 1992:43) Filosuf Amerika, John Dewey memandang bahwa pendidikan haruslah sebagai pembentuk watak dasar:

"the process of forming fundamental dispositions, intellektual and emotional, towards nature and fellow men." 'Pendidikan sebagai suatu proses pembentuk watak dasar, intelektual dan emosi yang berkaitan dengan lingkungan alam dan manusia'. Yang kemudian pendapat John Dewey menegaskan,

"Since education is a social process and there are many kinds of societies, a criterion for educational criticism and contruction implies a particular social ideal."

'Oleh karena pendidikan adalah proses sosial, dan masyarakat itu bermacam-macam, maka kriteria bagi kritik dan pembangunan pendidikan itu menunjukkan cita-cita sosial tertentu'. (Ahmad, 1992:19)

Rujukan gagasan John Dewey tentang konsep "learning by doing” mengarah pada konsep dalam surah Al-Baqarah:285 " "Kami dengar dan kami taat" sedangkan "learning by doing" yakni proses perolehan hasil belajar dengan mengerjakan tindakan-tindakan tertentu sesuai dengan tujuannya. Gagasan John Dewey dikembangkan oleh William $\mathrm{H}$. Kilpatrick dalam bentuk metode proyek, merupakan salah satu pemecahan masalah yang di terapkan secara luas dan setiap pemecahan masalah yang dialami dalam kehidupan sehari-sehari.

Di Raudatul Atfal anak belajar bersosialisasi melalui interaksi dengan teman sebaya, guru dan orang dewasa lainnya dengan penekanan norma ajaran agama Islam. Interaksi tersebut dapat memberikan kesempatan kepada anak untuk belajar, membantu, saling menyayangi, menghormati, saling percaya dan mengerti perasaan masingmasing. Selain itu melalui interaksi anak belajar tentang perilaku yang disenangi dan tidak disenangi, yang dibolehkan dan tidak dibolehkan, sehingga dari pengalaman itu diharapkan akan menghasilkan kesadaran sosial yakni perilaku-perilaku yang sesuai dengan aturan-aturan agama yang harus dipatuhi dan tidak berperilaku semaunya. 
Penelitian ini dilatar belakangi hasil pengamatan dan pengalaman peneliti dalam penggunaan metode pembelajaran di taman kanak-kanak, disini menggunakan metode proyek karena metode ini dianggap menarik dalam proses kegiatan pembelajaran anak usia dini sekaligus mampu mengembangkan kemampuan sosial anak. Disisi lain metode proyek tidak terfokus pada bidang kegiatan proyek konstruksi susun bidang balok saja, tetapi dapat digunakan guru dalam konsep merancang metode pembelajaran proyek pemecahan masalah, proyek apresiasi ataupun proyek latihan.

Dalam teorinya

Kilpatrick membagi metode proyek menjadi empat kelompok tipe, diantaranya:

1. Proyek konstruksi atau kreatif, tujuannya untuk mewujudkan sautu gagasan atau rencana bentuk lahiriah, seperti membangun perahu, mengarang cerita, membut jam dinding, membuat mobil-mobilan dengan bahan daur ulang, menggelar permainan.

2. Proyek apresiasi atau hiburan, tujuannya menikmati pengalaman estetis, seperti mendengarkan cerita, mendengarkan simponi atau bernyanyi, menikamti lukisan, dll.

3. Proyek masalah, tujuannya memecahkan suatu kesulitan intelektual, seperti mengapa embun jatuh pada waktu-waktu tertentu, mengapa terjadi banjir, mengapa es batu meleleh, mengapa noda di pakaian tidak bisa di bersihkan jika hanya dengan air, mengapa new york mempunyai pertumbuhan lebih cepat dari pada Philadelpia.

4. Proyek latihan dan belajar khusus, tujuannya memperoleh peningkatan keterampilan dan pengetahuan, seperti belajar mengenal angka dan huruf, belajar menulis, memperbaiki peringkat.

Adapun tujuan dari penelitian ini adalah :

1. Mengetahui pengaruh metode proyek terhadap kemampuan sosial anak di RA Al Chusnaniyah.

2. Mengetahui bahwa metode proyek dapat meningkatkan kemampuan sosial anak di RA Al Chusnaniyah.

\section{METODE PENELITIAN}

Jenis penelitian yang digunakan adalah penelitian kuantitatif hubungan dua variabel dengan desain penelitian 
menggunakan True Eksperimen Design dengan menggunakan PreTest-Post-Test Control Group Design, dalam disain ini responden dipilih secara random. Data kelompok dibagi dua, separuh diberi pelatihan (kelompok eksperimen) dan separuh lagi tidak diberi pelatihan (kelompok kontrol). Kelompok kontrol dan kelompok eksperiment diberi perlakukan dua kali pengukuran di depan (pre-test)

\section{HASIL PENELITIAN}

\section{Test distribusi normal}

Hasil dari uji normalitas yang dilakukan dengan menggunakan SPSS 25 menggunakan uji Kolmogorov-Smirnov pada tabel berikut :

One-Sample KolmogorovSmirnov Test Pretest

\begin{tabular}{|c|c|c|}
\hline & Eksperimen & Kontrol \\
\hline Statistic & .198 & .176 \\
\hline df & 15 & 15 \\
\hline Sig. & .119 & .200 \\
\hline
\end{tabular}

Posttest

\begin{tabular}{|c|c|c|}
\hline & $\begin{array}{c}\text { Eksperime } \\
\mathrm{n}\end{array}$ & Kontrol \\
\hline Statistic & .203 & .175 \\
\hline $\mathrm{df}$ & 15 & 15 \\
\hline Sig. & 200 & .095 \\
\hline
\end{tabular}

kemudian dilakukan perlakuan (treatment) setelah itu dilakukan pengukuran lagi (post-test). Instrumen yang digunakan berupa lembar observasi dan pendukung dokumentasi yaitu tes lisan yang sengaja diberikan untuk mengukur tingkat perkembangan kemampuan sosial anak. Pengukuran penelitian ini menggunakan check lis (daftar cocok). Uji stasitistik yang digunakan adalah uji $\mathrm{T}$

Kesimpulan:

Dari hasil tabel out put di atas dapat diketahui signifikasi skor pretest sebesar 0.119 untuk kelompok eksperimen dan 0.200 untuk kelompok kontrol. Untuk signifikasi skor posttest kelompok eksperimen sebesar 0.200 dan kelompok kontrol mendapati signifikasi sebesar 0.095 karena nilai signifikasi lebih besar dari 0,05 maka dapat disimpulkan bahwa kedua kelompok data mempunyai varian yang sama atau dapat dikatakan kedua data terdistribusi normal.

\section{Test Homogenitas}

$$
\text { Hasil dari uji }
$$

Homogenitas melalui lavene yang dilakukan dengan menggunakan SPSS 25 dapat dilihat pada tabel berikut: 
Test of Homogeneity of Variances

Pretest

\begin{tabular}{|l|c|c|c|c|}
\hline & $\begin{array}{c}\text { Levene } \\
\text { Statistic }\end{array}$ & df1 & df2 & df3 \\
\hline Based on Mean & .119 & 1 & 28 & .733 \\
\hline Based on Median & .215 & 1 & 28 & .646 \\
\hline $\begin{array}{l}\text { Based on Median and } \\
\text { with adjusted df }\end{array}$ & .215 & 1 & 26.207 & .646 \\
\hline Based on trimmed mean & .135 & 1 & 28 & .716 \\
\hline
\end{tabular}

Posttest

\begin{tabular}{|l|c|c|c|c|}
\hline & Levene Statistic & df1 & df2 & df3 \\
\hline Based on Mean & .307 & 1 & 28 & .584 \\
\hline Based on Median & .189 & 1 & 28 & .667 \\
\hline $\begin{array}{l}\text { Based on Median and } \\
\text { with adjusted df }\end{array}$ & .189 & 1 & 26.749 & .667 \\
\hline Based on trimmed mean & .276 & 1 & 28 & .604 \\
\hline
\end{tabular}

Kesimpulan :

Dari hasil tabel out put di atas dapat diketahui signifikasi pretest sebesar 0.733 dan posttest 0.584. Karena nilai signifikasi lebih dari 0,05 maka dapat disimpulkan bahwa kedua kelompok data mempunyai varian yang sama atau dapat dikatakan kedua data bersifat homogen.

\section{Uji t (t-test)}

Kriteria yang digunakan untuk menguji hipotesis $\mathrm{t}$ ini adalah memakai taraf signifikasi $\alpha=0,05$ Jika nilai signifikasi > 0,05 maka $\mathrm{H} 0$ diterima

Jika nilai signifikasi $<0,05$ maka H0 ditolak

Hasil dari uji kedua kelompok untuk Test kemampuan sosial anak dapat dilihat pada tabel berikut ini:

\section{Independent Samples Test}

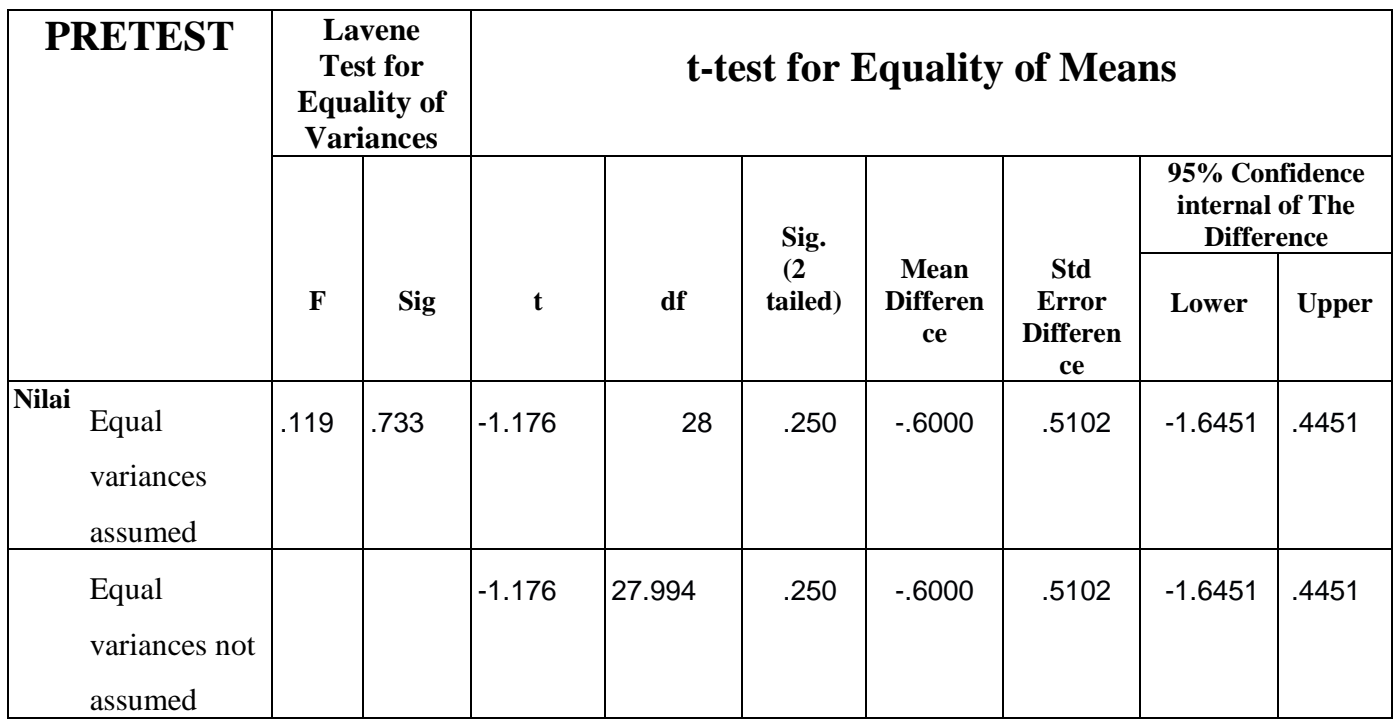




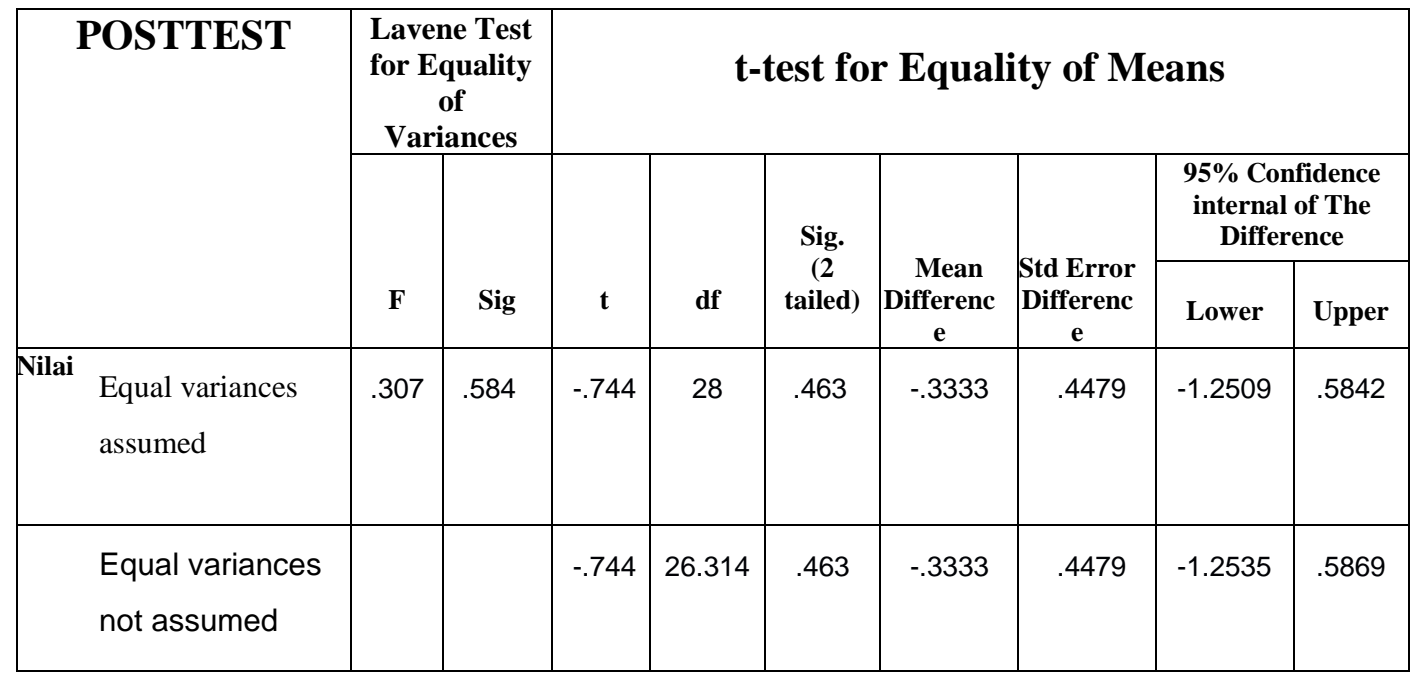

Pada Independent Samples Test pretest, terlihat nilai sig. 0.250 hal ini memperlihatkan bahwa tidak terdapat perbedaan hasil penilaian secara signifikan antara kelompok eksperimen dan kelompok kontrol. Selanjutnya pada Independent Samples Test posttest terlihat nilai sig. 0.463 antara kelompok eksperimen dan kelompok kontrol. Perbedaan mean sebesar 0,3 hal ini terlihat dari mean difference sebesar -0.3333 pada hasil nilai posttest dari kelompok eksperimen dan kelompok kontrol.

\section{PEMBAHASAN}

Test kemampuan sosial anak dapat dilihat pada tabel berikut ini:

Group Statistics

\begin{tabular}{|c|c|c|c|c|}
\hline \multicolumn{5}{|c|}{ Pretest } \\
\hline Kelompok & $\mathbf{N}$ & Mean & Std Deviation & Std Error Mean \\
\hline \multirow{2}{*}{$\begin{array}{ll}\text { Nilai } & \text { eksperimen } \\
& \text { kontrol } \\
\end{array}$} & 15 & 7.133 & 1.4075 & .3634 \\
\hline & 15 & & 1.3870 & \\
\hline \multicolumn{5}{|c|}{ Postest } \\
\hline Kelompok & $\mathbf{N}$ & Mean & Std Deviation & Std Error Mean \\
\hline \multirow{2}{*}{$\begin{array}{ll}\text { Nilai } & \text { Kontrol } \\
& \text { Eksperimen }\end{array}$} & 15 & 14.200 & 1.3732 & .3546 \\
\hline & 15 & 14.533 & 1.0601 & .2737 \\
\hline
\end{tabular}

Berdasarkan hasil pengolahan data diperoleh data bahwa rata-rata nilai posttest untuk kemampuan sosial anak di RA Al Chusnaniayah Surabaya pada kelompok eksperimen (kelas A2) lebih besar dari rata-rata nilai posttest kelompok kontrol (kelas A1). Hal tersebut dapat diketahui dari hasil nilai rata-rata posttest kelompok eksperimen 14.533 sedangkan kelompok kontrol hasil nilai rata-rata posttest 14.200 hanya terdapat perbedaan mean sebesar 0,3 hal ini terlihat dari mean difference sebesar -0.3333 .

Berdasarkan data yang ada 
dapat diambil kesimpulan bahwa dalam pembelajaran metode proyek guru berusaha membantu anak untuk meningkatkan aktivitas belajar dan meningkatkan kemampuan memecahkan masalah bersama kelompok sehingga aktivitas pengajaran dengan menggunakan metode proyek juga membantu anak didik untuk membiasakan meningkatkan ketrampilan dan menumbuhkan minat dalam memecahkan masalah kehidupan anak pada umumnya dan dalam kelompok sosialnya pada khususnya.

(Moeslichatoen, 2004:140)

\section{SIMPULAN}

Dari hasil penelitian diperoleh kesimpulan bahwa ada pengaruh yang lebih efektif untuk mengembangan kemampuan sosial anak di RA Al Chusnaniyah Surabaya dengan menggunaan metode proyek dalam pembelajaran di sekolah.

DAFTAR PUSTAKA

Abdullah dan Safarina. 2013. Sosiologi Pendidikan. Jakarta: PT Rajagrafindo Persada

Nugraha, Ali \& Rachmawati, Yeni. 2007. Metode Perkembangan Sosial emosional (Modul 1-12).

Jakarta: Universitas Terbuka.

Roopnarine, Jaipaul L. And James

E. Johnson. 2011.
Ahmad, Khursyid. 1992. Perinsip-perinsip

Pendidikan Islam.

Surabaya: Penerbit

Pustaka Progressif.

Arikunto, Suharsimi. 2010. Metode Penelitian. Jakarta : PT. Rineka Cipta.

Arifin, M.PD, Drs. Zainal. 2011. Konsep dan Model Pengembangan

Kurikulum. Bandung: PT Remaja Rosdakarya

Bahreisy, Salim dan Said Bahreisy. 1987. Tafsir Ibnu Katsir. Surabaya: PT Bina Ilmu Offset

Moeslichatoen, 2004. Metode Pengajaran Di Taman Kanak-kanak. Jakarta: PT Rineka Cipta.

Mulyasa, H.E.Prof.Dr.M.Pd.

2012. Manajemen PAUD,

Bandung: PT Remaja

Rosdakarya

Nielsen. Dianne Miller. 2011.

Mengolah Kelas untuk

Guru TK, Jakarta: Indeks

Noor, Juliansyah. 2011. Metodologi Penelitian: Skripsi, Tesis, Disertasi, dan Karya Ilmiah. Jakarta: Prenadamedia Group.

Pendidikan Anak Usia

Dini: Dalam Berbagai Pendekatan. Jakarta: KENCANA. Santrock, John. 2007. Perkembangan Anak. Jakarta: Penerbit Erlangga 
Shihab, Dr.Quraish. 2000.

TAFSIR AL-MISBAH.

Jakarta: Penerbit Lentera

Hati.

Sujiono, Yuliani. 2009. Konsep

Dasar Pendidikan Anak

Usia Dini. Jaklarta:

Indeks.

Sudjarwo, Prof.Dr. 2015. Proses

Sosial dan Interaksi Sosial

dalam Pendidikan.

Bandung: CV Mandar

Maju

Thoifah, I'anatut. 2015. Statistika

Pendidikan dan Metode

Penelitian Kuantitatif.

Jatim: Madani.

Widoyoko, Eko Putro. 2012.

Teknik Penyusunanb

Instrumen Penelitian.

Yogyakarta: Pustaka

Pelajar

Yus, Dr.Anita, MPd. 2011. Model

Pendidikan Anak Usia

Dini. Jakarta: Prenada

Media Group. 